\title{
Transcription of Brain Natriuretic Peptide and Atrial Natriuretic Peptide Genes in Human Tissues*
}

\author{
ALEXANDER L. GERBES $\dagger$, LINA DAGNINO $\ddagger$, THAN NGUYEN§, AND \\ MONA NEMERT
}

Laboratory of Molecular Genetics (A.L.G., L.D., T.N., M.N.), Clinical Research Institute, Montreal, Canada; and Klinikum Grosshadern (A.L.G.), Department of Medicine II, University of Munich, 81366 München, Federal Republic of Germany

\begin{abstract}
We have compared the expression of atrial natriuretic peptide (ANP) and brain natriuretic peptide (BNP) genes in various human tissues using a quantitative polymerase chain reaction technique. Tissues of three human subjects, obtained at autopsy, were analyzed. BNP transcripts could be detected in the central nervous system, lung, thyroid adrenal, kidney, spleen, small intestine, ovary, uterus, and striated muscle. ANP transcripts could also be demonstrated in various human extracardiac tissues including several endocrine organs. In all periph-
\end{abstract}

eral tissues, the level of both natriuretic peptide transcripts was approximately 12 orders of magnitude lower than in cardiac ventricular tissues. This distribution is in marked contrast to the much lower level of ANP and BNP transcripts present in extracardiac rat tissues (generally less than $1 / 1000$ of ventricles). These data suggest differential expression of the two natriuretic peptide genes in cardiac and extracardiac tissues in man. Furthermore, the presence of local synthesis of ANP and BNP in various peripheral oryans suggests paracrine and/or autocrine function of these natriuretic peptides. ( $J$ Clin Endocrinol Metab 78:1307-1311, 1994)
$\mathrm{T}$ HE CARDIAC hormones atrial natriuretic peptide (ANP) and brain natriuretic peptide (BNP) exhibit similar pharmacological profiles, such as natriuresis and smooth muscle relaxation (1). Along with these common properties there are striking dissimilarities: Whereas the structure of ANP is highly conserved among different species, there is considerable variation of the amino acid sequence of BNP. Furthermore, there are differences regarding their tissue distribution. The heart is the major site of synthesis of ANP, but low levels of ANP transcription have also been found in various other tissues of different species (2-13), including human where ANP messenger RNA (mRNA) has been detected in heart (2) and thymus (12). Although originally identified and isolated from the porcine brain (14) BNP has been shown to be mainly a cardiac hormone; in fact, all BNP complimentary DNA (cDNAs), porcine $(15,16)$, rat (17), and human (18) were isolated from cardiac $\mathrm{CDNA}$ libraries. Tissue distribution of BNP has been studied in rat at the peptide (19-21) and mRNA (22) levels. In human, BNP peptide was described in atria and ventricles (23-25) and more recently in brain (26).

Received July 20, 1993. Accepted February 1, 1994.

Address correspondence and requests for reprints to: Priv. Doz. Dr. Alexander L. Gerbes, Medizinische Klinik II, Klinikum Grosshadern, Universität München, Marchioninistraße 15, 81366 München, Federal Republic of Germany.

* Parts of these data were presented at the Ninth International Congress of Endocrinology, Nice, France, September 1992. This work was supported by the Medical Research Council and the Heart and Stroke Foundation of Canada (to M.N.).

† Supported by a ASCHE stipendium of the Deutsche Gesellschaft für Verdauungs- und Stoffwechselkrankheiten and by the Fond de la Recherche en Santé de Quebec.

$\ddagger$ Fellow of the HSFC.

$\S$ Recipient of a summer bursary from the FRSQ.

I McDonald scholar of the HSFC.
The presence of BNP immunoreactivity in human (26) and porcine $(14)$ but not rat $(19,21)$ brain raises the question of species specific distribution of the peptide. Therefore we undertook the analysis of ANP and BNP gene expression in extracardiac human tissues using quantitative PCR amplification of human ANP and BNP transcripts.

\section{Subjects and Methods}

Tissues

Human tissues were obtained from three subjects at autopsy

\section{Subjects}

Subject A: female, $57 \mathrm{yr}$, with metastatic ovarian carcinoma (heart weight: $310 \mathrm{~g}$ ); subject B: male, $57 \mathrm{yr}$, suffered from cardiac hypertrophy (heart weight: $640 \mathrm{~g}$ ) and died of cardiac arrest; subject $\mathrm{C}$ : female, 33 yr, suffered cardiogenic shock after coronary artery dissection (heart weight: $340 \mathrm{~g}$ ). Tissue samples were frozen in liquid nitrogen and maintained at $-80^{\circ} \mathrm{C}$ until RNA extraction.

RNA extraction. Total RNA was extracted by the guanidinium thiocyanide method (27). The integrity of RNA preparations was assessed by electrophoresis on agarose gels; RNA samples were quantified by measuring UV absorbance at $260 \mathrm{~nm}$ and by dot blot hybridization to endlabeled $\mathrm{p}(\mathrm{dt})_{12-18}$.

CDNA synthesis. Samples of $2 \mu \mathrm{g}$ total RNA were mixed with $2 \mu \mathrm{g}$ $\mathrm{p}(\mathrm{dT})_{12-18}$ (Sigma, St. Louis, MO), fifteen units of avian myeloblastosis virus transcriptase (Promega, Madison, WI) and 34 U RNA inhibitor (Pharmacia, Piscataway, NJ), as described previously (22). After incubation at $37^{\circ} \mathrm{C}$ for $1.5 \mathrm{~h}$ cDNA samples were used directly for polymerase chain reaction (PCR) amplification.

$P C R$ amplification of ANP and BNP transcripts. The sense and antisense primers used to amplify ANP (sense primer 5 '-CTTGACGACGCCAG CATGAGC, antisense primer 5'-TCCGCTCTGGGCTCCAATCCT) and BNP (sense primer $5{ }^{\prime}$-TTCCTGGGAGGTCGTTCCCAC, antisense primer $5^{\prime}$-CATCTTCCTCCCAAAGCAGCC) templates corresponded 
to sequences in the first and second exons of the respective genes ( 28 29). The amplification of ANP and BNP was carried out using various amounts from the same preparations of CDNA.

cDNA was subjected to 22-25 cycles of PCR amplification using 10 U Vent polymerase (New England BioLabs, Beverly, MA). As an internal control for the amplification process, human genomic DNA was used; the principle of this quantitative PCR technique has been described in detail previously (30). Amplification of the cDNA and genomic DNA templates yielded 445 base pairs (bp) and $576 \mathrm{bp}$ fragments for ANP and $291 \mathrm{bp}$ and $522 \mathrm{bp}$ fragments for BNP, respectively. Amplification products were separated by agarose gel electrophoresis and transferred to nylon membranes (Hybond, Amersham, UK). The DNA was then hybridized to end-labeled oligonucleotides $\left(\gamma-{ }^{32} \mathrm{P}\right.$-ATP $2000 \mu \mathrm{Ci} / \mathrm{mmol}$, T4-polynucleotide kinase) corresponding to sequences located between the two PCR primers in ANP (5'-GTCCATCCTGCCCCCGAAGCAGCT) and BNP (5'-AGACCCTTGCACCATCTTGGGGC) genes, respectively. Quantification was performed by image analysis densitometry of the hybridization bands. PCR experiments were performed using two CDNA preparations and conducted at least twice.

\section{Results}

\section{Quantitative amplification of ANP and BNP sequences}

Optimal conditions for quantitative PCR require initial amounts of DNA template and numbers of PCR cycles yielding an exponential phase of amplification. Optimization of these conditions has been elaborated in detail previously $(22,30)$. Sixty nanograms of cardiac cDNA and $660 \mathrm{ng}$ extracardiac cDNA with $425 \mathrm{ng}$ genomic DNA and 22 cycles for cardiac and $85 \mathrm{ng}$ genomic DNA and 25 cycles for extracardiac tissues were found to be in the linear range. With these amplification conditions, the yield of DNA products was directly proportional to the initial amounts of template, both for ANP and BNP (Fig. 1, a, b). Coamplification of genomic DNA did not affect the yield of amplification products from cDNA templates as illustrated for amplification of BNP in cardiac cDNA (Fig. 2).

\section{$A N P$ and BNP transcripts in various tissues}

Figure 3 demonstrates BNP expression in various extracardiac tissues. ANP and BNP transcripts were quantified by calculating the relative abundance of the respective cDNA compared to the genomic DNA. Average atrial abundance of ANP was 20- to 50-fold higher than ventricular abundance and both, ANP and BNP expression was clearly more abundant in ventricles than in the other tissues examined. Therefore extracardiac expression was compared to ventricular values. Abundance of transcripts in extracardiac tissues was at least one (subject A) or two (subject B) orders of magnitude lower than in ventricular tissue. Table 1 summarizes the expression of ANP and BNP found in various cardiac and extracardiac tissues of male and female subjects. In addition to the values shown for BNP and ANP in ventricles, BNP and ANP cDNA were quantitated in the ventricles of several controls (BNP: 20-45, ANP: 20-35 cDNA/total DNA $\left(\% \times 10^{-6}\right)$ and several patients with cardiac hypertrophy (BNP: 200-600, ANP: $60-120$ cDNA/ total DNA $\left(\% \times 10^{-6}\right)$. Thus, the levels of BNP and ANP in normal (subject $A$ and $C$ ) and diseased (subject $B$ ) human ventricles are representative of a larger sample size. It was of interest to note that normal tissue of the ovary of female
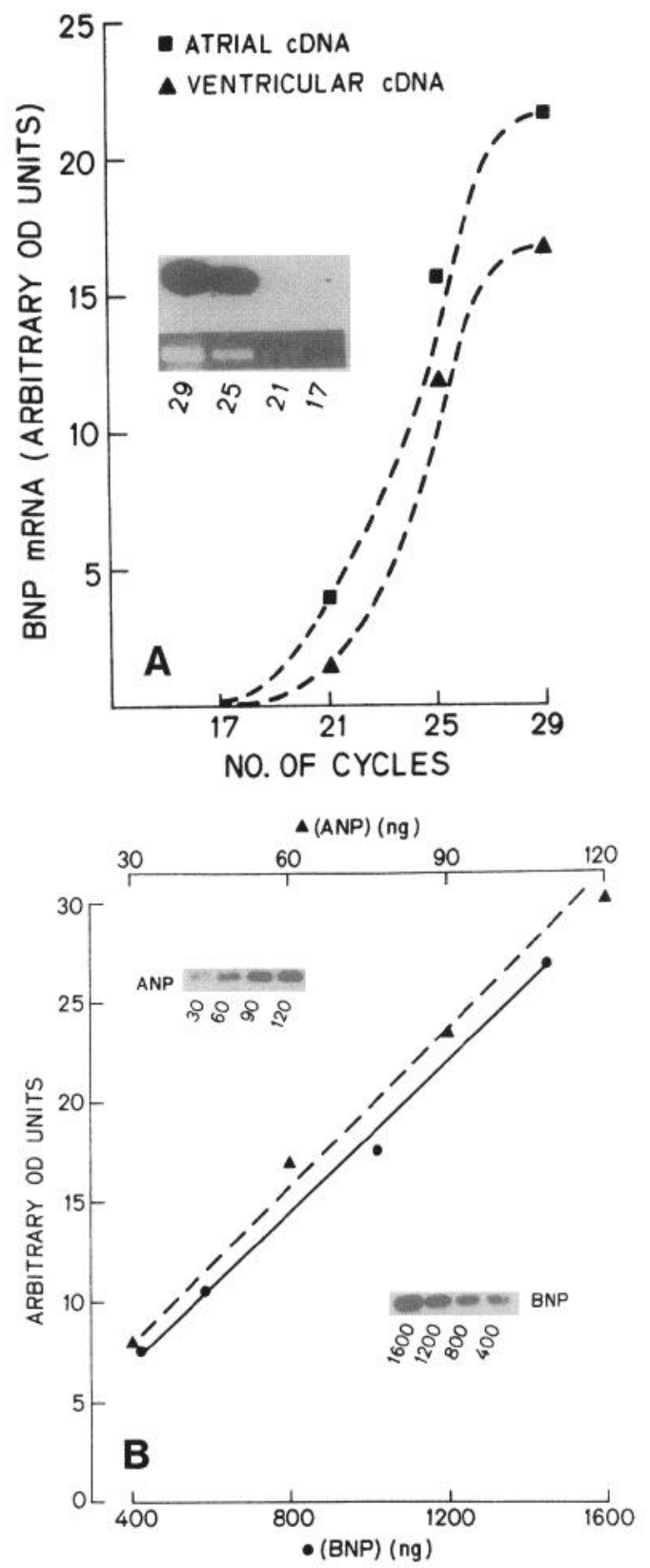

FIG. 1. a, Amplification of BNP transcripts of atrial (ש) and ventricular $(\mathbf{\Lambda})$ cDNA. Amplification products expressed as arbitrary OD units of densitometry of Southern blot are correlated with the number of PCR cycles. Exponential amplification is observed up to 25 cycles. b, Amplification of ANP transcripts of atrial cDNA $(\mathbf{\Delta})$ and of BNP transcripts of genomic DNA (-). Amplification products expressed as arbitrary OD units of densitometry of Southern blot are correlated with the amount of DNA input. Linear relation of initial DNA and amplification products is observed throughout.

A (with ovarian carcinoma) showed the highest extracardiac expression of ANP and even more so, of BNP. Indeed, the levels of BNP transcripts were similar in ovaries and ventricles. This prompted us to analyze the level of BNP in nondiseased ovaries. Subject $C$ with a normal ovary shows pituitary and lung BNP expression comparable to that of subject A (Table 2) but a 20 -fold lower abundance of ovarian 
PCR amplification of human BNP sequences

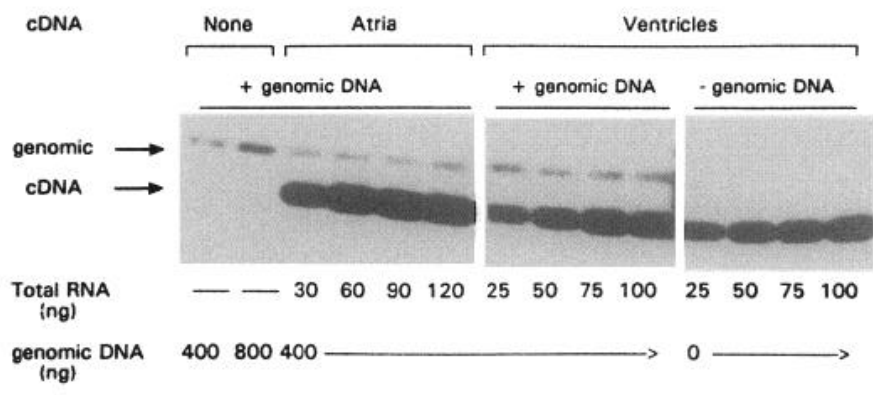

FIG. 2. Amplification of BNP transcripts of increasing amounts of atrial and ventricular cDNA. Coamplification with genomic DNA does not affect the yield of amplification products.

BNP transcripts in extracardiac human tissues
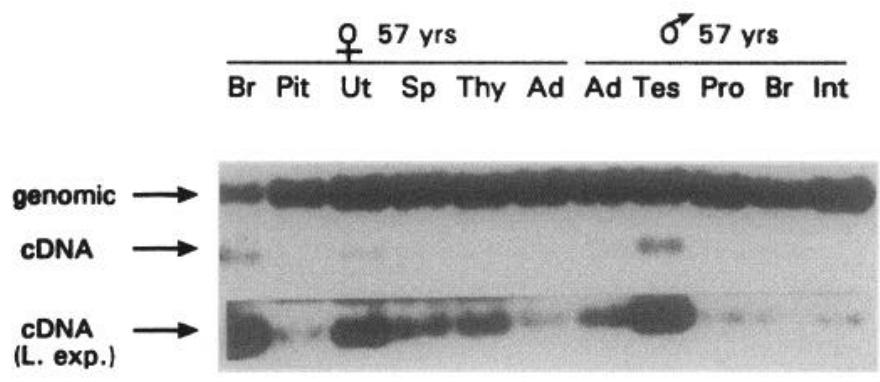

FIG. 3. BNP transcripts in various extracardiac human tissues of subject A (female, $57 \mathrm{yr}$ ) and subject $\mathrm{B}$ (male, $57 \mathrm{yr}$ ). cDNA was coamplified with constant amounts of genomic DNA. The lower lane shows Southern blot of cDNA at longer exposure. Br, Brain; Pit, pituitary; Ut, uterus; Sp, spleen; Thy, thyroid; Ad, adrenal; Tes, testis; Pro, prostate; Int, small intestine.

BNP transcripts than subject A. Thus, it appears that BNP transcripts are specifically increased in normal tissue of the ovaries of a patient with ovarian carcinoma. Comparing the expression of ANP and BNP, the most marked difference of abundance in subject A was observed in the kidney, exhibiting more ANP than BNP transcripts. Consistent with published reports (25), subject B with cardiac hypertrophy showed stimulated levels of both ANP and BNP transcripts and a higher ratio of cardiac BNP/ANP. However, the increase in ventricular ANP and BNP transcripts was not accompanied by systematically elevated levels of ANP and BNP transcripts in extracardiac tissues where little if any variation was observed. Interestingly, there was much less ANP than BNP in testicular tissue. In fact, the ratio of BNP to ANP was variable in the different tissues examined suggesting differential expression of the two natriuretic peptide genes. Neither ANP nor BNP expression could be detected in liver or pancreas of any of the subjects investigated although tubulin transcripts were detected and served as control for the integrity of the RNA and cDNA preparations (data not shown).

\section{Discussion}

The family of natriuretic peptides includes, in addition to ANP, two other members, BNP and CNP (C-type natriuretic peptide). All three peptides share structural similarities and, in the case of ANP and BNP, bind with similar affinities to the same guanylate cyclase linked receptors (31). Recent studies, including our own, have shown that BNP and ANP are differentially expressed in heart atria and ventricles suggesting distinct functional roles for these two hormones (22, 25). Despite its initial discovery in porcine brain about $5 \mathrm{yr}$ ago, surprisingly little is known about BNP gene expression in extracardiac tissues. Indeed BNP transcripts have so far been detected in a very limited number of rat tissues, brain; lung; and aorta, at levels generally 100-fold lower than ventricles (22). This is in contrast to numerous reports which have documented the presence of ANP gene expression in several extracardiac tissues (reviewed in Refs. 2 and 3). The present study demonstrates significant levels of BNP tran-

TABLE 1. Expression of BNP and ANP in various human tissues

\begin{tabular}{|c|c|c|c|c|}
\hline & \multicolumn{2}{|c|}{ Subject A } & \multicolumn{2}{|c|}{ Subject B } \\
\hline & $\begin{array}{l}\text { BNP cDNA/total } \\
\text { cDNA }\left(\% \times 10^{-6}\right)\end{array}$ & $\begin{array}{l}\text { ANP cDNA/total } \\
\text { cDNA }\left(\% \times 10^{-6}\right)\end{array}$ & $\begin{array}{l}\text { BNP cDNA/total } \\
\text { cDNA }\left(\% \times 10^{-6}\right)\end{array}$ & $\begin{array}{l}\text { ANP CDNA/total } \\
\text { cDNA }\left(\% \times 10^{-6}\right)\end{array}$ \\
\hline Left ventricule & 23 & 20 & 595 & 69 \\
\hline CNS & 2.34 & 1.02 & 0.82 & ND \\
\hline Pituitary & 1.15 & Undet. & 1.34 & ND \\
\hline Thyroid & 2.25 & 1.05 & ND & ND \\
\hline Lung & 2.01 & 2.33 & 0.34 & 0.15 \\
\hline Kidney & 0.48 & 3.80 & 0.34 & 0.29 \\
\hline Adrenal gland & 0.75 & 0.38 & 0.68 & ND \\
\hline Liver & Undet. & Undet. & Undet. & Undet. \\
\hline Pancreas & Undet. & ND & ND & ND \\
\hline Spleen & 0.83 & 1.50 & 0.59 & ND \\
\hline Small intestine & $\mathrm{ND}$ & ND & 0.69 & 0.22 \\
\hline Prostate & & & 0.35 & ND \\
\hline Testis & & & 2.92 & Undet. \\
\hline Ovary & 16.79 & 6.70 & & \\
\hline Uterus & 1.56 & 3.34 & & \\
\hline Striated muscle & ND & ND & 0.71 & 0.65 \\
\hline
\end{tabular}

Undet., Undetected; ND, not determined. 
TABLE 2. Expression of BNP in various human tissues (BNP cDNA/total cDNA $\left(\% \times 10^{-6}\right)$

\begin{tabular}{lcc} 
& Subject C & Subject A \\
\hline Ventricle & 45 & 23 \\
Pituitary & 1.73 & 1.15 \\
Lung & 0.41 & 2.01 \\
Liver & Undet. & Undet. \\
Pancreas & Undet. & Undet. \\
Ovary & 0.86 & 16.79 \\
\hline
\end{tabular}

Undet., Undetected.

scription in extracardiac human tissues. Indeed, whereas the level of BNP transcription in control, nondiseased human ventricle was almost identical to the level of BNP transcripts detected by the same PCR approach in rat ventricles (22), the level of BNP transcripts in extracardiac human tissues was generally 1 and often 2 orders of magnitude higher than the level detected in rat extracardiac tissues. For example, in rat, the abundance of BNP mRNA in brain or lung was 1000 fold lower than in ventricles whereas in human tissues of two subjects (with no history of cardiovascular disorders) brain and lung BNP mRNA levels were only 10- to 20 -fold lower than in ventricles.

The finding that several endocrine organs contain appreciable levels of BNP mRNA raises the possibility that extracardiac tissues might contribute to circulating BNP levels in human. The contribution of extracardiac tissues to plasma BNP was raised by Mukoyama et al. (25) as a possible explanation for the differential clearance of ANP and BNP from the circulation. The presence of BNP transcripts does not prove that the peptide will also be synthesized. However, so far there is no evidence for translational control of either BNP or ANP, and the presence of BNP and ANP transcripts and their regulation has been generally paralleled by similar regulation at the peptide. level $(1,22,25)$. The finding of ANP transcripts in central and peripheral organs is in agreement with the demonstration of ANP mRNA in several extracardiac tissues of other species like mouse, rat, or chicken $(2,3)$ and therefore suggests a conserved tissue distribution of ANP across species. Interestingly, the ratio of BNP to ANP in brain and adrenal was 2:1 which is in perfect agreement with the reported ratio of BNP to ANP peptide in porcine brain (32) and bovine adrenal (33).

The presence of both ANP and BNP transcripts in reproductive organs is noteworthy. ANP precursor has previously been detected in rat testis (13) and ovaries (34), together with specific ANP/BNP receptors in these tissues (34). The finding that the BNP gene is also transcribed in ovaries merits further investigation particularly in view of the dramatically elevated levels of BNP in normal tissue of the ovaries of subject $A$ who had an ovarian carcinoma relative to BNP levels in intact ovaries. Indeed, as shown in Table 2, BNP mRNA levels were either similar or 2 -fold higher in ventricles, pituitary, and lung of subject $A$ whereas ovarian BNP mRNA were 20 -fold increased, and reached levels comparable to ventricles.

Finally, both ANP and particularly BNP transcripts were markedly elevated in the ventricles of subject $B$ who had cardiac hypertrophy. This is in agreement with reports show- ing greater induction of BNP than ANP in pathophysiological conditions of the heart $(25,30)$. Interestingly, extracardiac ANP and BNP levels were not increased concomitantly with increased ventricular BNP and ANP. Furthermore the ratio of BNP to ANP transcripts was variable in the different tissues examined. Thus, our data argue for a differential tissue-specific regulation of the BNP gene. Together with the differential tissue distribution of various natriuretic peptide receptors (35), our findings underscore the diversity of the dual ANP/BNP natriuretic peptide system and could further stimulate the investigation of their functional importance in peripheral tissues.

\section{Acknowledgments}

Marie-Claude Grenier was of great help with the densitometric image analysis of Southern blots. Lise Laroche and Florian Anselm are thanked for secretarial assistance. Michel Chamberlain, Paul Lavender, and Marc Therrien are thanked for helpful discussions. We are grateful for the support of Jacques Drouin and Gustav Paumgartner.

\section{References}

1. Lang CC, Choi AM, Struthers AD. 1992 Atrial and brain natriuretic peptide: dual natriuretic peptide system potentially involved in circulatory homeostasis. Clin Sci. 83:519-527.

2. Gutkowska J, Nemer M. 1989 Structure, expression, and function of atrial natriuretic factor in extraatrial tissues. Endocr Rev. 19:519536.

3. Vollmar AM. 1990 Atrial natriuretic peptide in peripheral organs other than the heart. Klin Wochenschr. 68:699-708.

4. Ritter D, Needleman P, Greenwald JE. 1991 Synthesis and secretion of an atriopeptin like protein in rat kidney cell culture. J Clin Invest. 87:208-212.

5. Gardener DG, Deschepper CF, Ganong WF, et al. 1986 Extraatrial expression of the gene for atrial natriuretic factor. Proc Natl Acad Sci USA 83:6697-6699.

6. McKenzie JC, Tanaka I, Misono KS, Inagami T. 1985 Immunocytochemical localisation of atrial natriuretic factor in the kidney, adrenal medulla, pituitary and atrium of rat. J Histochem Cytochem. 33:828-836.

7. Ong H, Lazure C, Nguyen TT, et al. 1987 Bovine adrenal chromaffine granules are a site of synthesis of atrial natriuretic factor. Biochem Biophys Res Commun. 147:957-963.

8. Vollmar AM, Friedrich A, Sinowatz F, Schulz R. 1988 Presence of atrial natriuretic peptide like material in guinea pig intestine. Peptides. 9:965-971.

9. Vuolteenaho O, Arjamaa O, Vakkuri O, et al. 1988 Atrial natriuretic peptide (ANP) in rat gastrointestinal tract. FEBS Lett. 233:7982.

10. Gerbes AL, Denecke H, Cantin M, Nathrath W. 1991 Presence of atrial natriuretic factor prohormone in enterochromaffine cells of the human large intestine. Gastroenterology. 101:424-429.

11. Chabot JG, Morel G, Belles-Isle M, Jeandel L, Heisler S. 1988 ANF and exocrine pancreas: ultrastructural autoradiographic localization in acinar cells. Am J Physiol. 254:E301-E309.

12. Vollmar AM, Schulz R. 1990 Atrial natriuretic peptide is synthesized in the human thymus. Endocrinology. 126:2277-2281.

13. Vollmar AM, Friedrich A, Schulz R. 1990 Atrial natriuretic peptide precursor material in rat testis. J Androl. 11:471-475.

14. Sudoh T, Kangawa K, Minamino N, Matsuo H. 1988 A new natriuretic peptide in porcine brain. Nature. 332:78-81.

15. Maekawa K, Sudoh T, Furusawa M, et al. 1988 Cloning and sequence analysis of cDNA encoding a precursor for porcine brain natriuretic peptide. Biochem Biophys Res Commun. 157:410-416.

16. Porter JG, Arfsten A, Palisi T, Scarborough RM, Lewicki JA, Seilhamer JJ. 1989 Cloning of a cDNA encoding porcine brain natriuretic peptide. J Biol Chem. 264:6689-6692. 
17. Kambayashi $Y$, Nakao K, Itoh $\mathbf{H}$, et al. 1989 Isolation and sequence determination of rat cardiac natriuretic peptide. Biochem Biophys Res Commun. 163:233-240.

18. Sudoh T, Maekawa K, Kojima M, Minamino N, Kangawa K, Matsuo H. 1989 Cloning and sequence analysis of cDNA encoding a precursor of human brain natriuretic peptide. Biochem Biophys Res Commun. 159:1427-1433.

19. Aburaya M, Minamino N, Hino J, Kangawa K, Matsuo H. 1989 Distribution and molecular forms of brain natriuretic peptide in the central nervous system, heart and peripheral tissue of rat. Biochem Biophys Res Commun. 165:880-887.

20. Ogawa Y, Nakao K, Mukoyama M, et al. 1990 Rat brain natriuretic peptide-tissue distribution and molecular form. Endocrinology. 165:2225-2227.

21. Nakao K, Itoh H, Kambayashi $\mathbf{Y}$, et al. 1990 Rat brain natriuretic peptide. Isolation from rat heart and tissue distribution. Hypertension. 15:774-778.

22. Dagnino L, Drouin J, Nemer M. 1991 Differential expression of natriuretic peptide genes in cardiac and extracardiac tissues. Mol Endocrinol. 5:1292-1300.

23. Tateyama $H$, Hino J, Minamino $N$, Kangawa $K$, Ogihara $T$, Matsuo H. 1990 Characterization of immunoreactive brain natriuretic peptide in human cardiac atrium. Biochem Biophys Res Commun. 166:1080-1087.

24. Kambayashi Y, Nakao K, Mukoyama M, et al. 1990 Isolation and sequence determination of human brain natriuretic peptide in human atrium. FEBS Lett. 259:341-345.

25. Mukoyama M, Nakao K, Hosoda K, et al. 1991 Brain natriuretic peptide as a novel cardiac hormone in humans. J Clin Invest. 87:1402-1411.

26. Takahashi K, Totsune $\mathbf{K}$, Sone $\mathbf{M}$, et al. 1992 Human brain natriuretic peptide-like immunoreactivity in human brain. Peptides. 13:121-123.

27. Chomczynski P, Sacchi N. 1987 Single step method of RNA isolation by acid guanidinium thiocyanate-phenol-chloroform extraction. Anal Biochem. 162:156-159.

28. Nemer M, Chamberland M, Sirois D, et al. 1984 Gene structure of human cardiac hormone precursor, pronatriodilatin. Nature. 312:654-656.

29. Seilhamer JJ, Arfsten A, Miller JA, et al. 1989 Human and canine gene homologs of porcine brain natriuretic peptide. Biochem Biophys Res Commun. 165:650-658.

30. Dagnino L, Nemer M. 1992 Increased transcripts for B-type natriuretic peptide in spontaneously hypertensive rats. Quantitative polymerase chain reaction for atrial natriuretic and brain natriuretic peptide transcripts. Hypertension. 20:690-700.

31. Chinkers M, Garbers DL, Chang MS, et al. 1989 A membrane form of guanylate cyclase is an atrial natriuretic peptide receptor. Nature. 338:78-83.

32. Ueda S, Minamino N, Sudoh T, Kangawa K, Matsuo H. 1988 Regional distribution of immunoreactive brain natriuretic peptide in porcine brain and spinal cord. Biochem Biophys Res Commun. 155:733-739.

33. Nguyen TT, Lazure C, Babinski K, Chrétien M, De Léan A, Ong H. 1989 Purification and primary structure of proaldosterone secretion inhibitory factor from bovine adrenal chromaffine cells. Mol Endocrinol. 3:1823-1829.

34. Gutkowska J, Tremblay J, Antakly T, Meyer R, MukaddamDaher S, Nemer M. 1993 The atrial natriurctic peptide system in rat ovaries. Endocrinology. 132:693-700.

35. Wilcox JN, Augustine A, Goeddel DV, Lowe DG. 1991 Differential regional expression of three natriuretic peptide receptor genes within primate tissues. Mol Cell Biol. 11:3454-3462. 